\title{
Internet banking adoption in Egypt: Extending technology acceptance model
}

\author{
Shaymaa Farid Fawzy \\ Arab Academy for Science and Technology and Maritime Transport \\ College of Management \& Technology, Egypt \\ Dar Uloom University, KSA \\ Nermine Esawai \\ Arab Academy for Science and Technology and Maritime Transport \\ College of Management \& Technology, Egypt
}

\section{Keywords}

Internet banking, website characteristics, perceived privacy \& security, TAM, computer efficacy

\begin{abstract}
:
The increased expansion of E-commerce and internet along with the development of technology has changed business operations and functioning. Internet banking is considered an opportunity for banks to have differentiated services provided for their customers. The purpose of this paper is to investigate the factors that affect customers' adoption of internet banking in Egypt in light of technology acceptance model (TAM). The study adopted a quantitative approach through distributing questionnaires in public and private banks' customers operating in Egypt.

The results indicated that website characteristics, computer efficacy, and perceived risk had a direct impact on customers' adoption of internet banking. These variables were considered an extension to TAM when studying internet banking adoption. It is suggested that financial banks give continuous attention to their websites and provide their customers with easy and useful access to internet banking services. Banks should be concerned with inhibitors of internet banking such as perceived risk in order to keep existing customers and attract new ones.

This paper is the first to investigate the factors that affect customers' adoption of internet banking in Egypt after banks introduced many of their services over their websites.
\end{abstract}

Corresponding author: Shaymaa Farid Fawzy

Email address for corresponding author: sfaridfawzy@gmail.com

First submission received: 12th April 2017

Revised submission received: 26th June 2017

Accepted: 10th August 2017

\section{Introduction}

Dramatic changes regarding banks' operation have emerged due to the rapid expansion of information technology. The Internet expanded the growth of the banking industry, along with other industries. This is considered a new opportunity to develop their service (Chechen et al., 2016). The internet banking replaces the visit to bank branches and decreases fixed costs. According to Arunachalam and Sivasubra-manian (2007), Internet banking is when a customer has the ability to access his/her bank account through the internet or mobile phone. Nowadays, customers are welcoming the shift from using traditional banking services offline to benefiting from all banking services online (Qureshi et al., 2008). This is because customers value the high level of usefulness and ease of use of internet banking services online.

In less developed countries, very few banks offer internet banking services other than the services of providing their customers with information about products and services offered by the bank. Internet banking services were first offered through banks' promotional activities and 
advertisements. But today customers can execute financial activities and transactions easily and directly through internet banking services. According to Akhlaq and Ahmed (2013); Rahman (2009), internet banking activities include transferal of funds, loan applications, online payments, investment activities, opening or modifying deposit account, exchange rates, bill payments, account details, pay credit cards by direct debit or manual transfers, view credit card statements, online statements or check account balance.

\section{Internet Banking in Egypt}

E-Banking services proved to be financial benefits to the adopting banks. In developed countries, banks have recognized the importance of adopting e-banking services on the banks' overall performance whether financial or marketing operations. E-banking services were introduced in Egypt to retain existing customers and attract new ones. Egypt had three banking categories: 1 . Commercial banks. 2. Business \& investment Banks. 3. The Central Bank of Egypt (CBE) is the banking industry regulator. CBE regulates banking and monetary system, credit \& banking, banking policy \& dealing with the daily settlement of clearings. The Egyptian banking sector adopted Internet banking services to manage the relationship with customers such as HSBC, QNB, SABB, Cre'ditAgricole, BanqueMisr, NBAD, Citibank Egypt, Arab Bank, Piraeus bank, BNP Paribas Egypt, Barclays, and CIB. The first bank introducing internet banking service in Egypt was Citibank. Although many banks are offering internet banking services, these services are limited and do not extend to third party transactions such as paying a bill or transferring funds to another bank customer's account.

Although internet banking provides a wide variety of services online and is characterized by a high level of convenience, it is still not accepted by many people in Egypt due to the problem of security and privacy in addition to the perceived risk. Customers are unwilling to provide their personal details and their credit/ debit card information over the internet. The aim of this research is to investigate the factors that affect internet banking adoption.

\section{Model development and hypotheses}

According to Adam et al., (1992) TAM, perceived usefulness and perceived ease of use influence one's attitude toward system usage. It was also reported by McKenzie et al., (2006) that TAM helps in understanding the factors that affect users' acceptance of internet in financial services. Despite TAM popularity in many studies such as Ariff (2014) \& Abdel Kader (2013) TAM was criticized by a number of researchers in different studies and in different contexts (Farid, 2012). Theory of Reasoned Action (TRA) developed by Fishbein and Ajzen (1975), and Theory of Planned Behavior (TPB) developed by Ajzen on an extension to TRA and TAM agree that behavioral intentions are a function of attitude (EINaggar, 2010; Shih \& Fang, 2004). TPB was employed in many studies concerned with indicating the factors affecting consumer behavior in e-commerce, online shopping (Farid,2012) Internet banking adoption (Kamyab\&Delafrooz, 2016; Shi et. al, 2008). According to AIDA model procedures and steps of adoption process are awareness, interest, evaluation, trial and finally adoption.

\subsection{Website characteristics:}

Customers use internet banking services to interact with the bank website. It is important that the website provides customers with the needed services and information to complete their transactions successfully (Alhudajthy\& Kitchen, 2009). Websites should be characterized by clarity of information, high-speed level for uploading or downloading, highly secured (especially to money transactions), easiness and user friendly. Internet banking provides customers with a unique advantage of offering bank services and allowing transactions from any location at any time (Ndubisi\&Sinti, 2006; Kesharwani\&Bisht, 2012). According to Ortega et al., (2007), website design is considered one of the reasons for having a successful internet banking adoption and that the failure 
of some financial entities adopted internet banking was because of poor website characteristics s and other factors as well.

H1. Website characteristics have a positive effect on perceived ease of use of internet banking technology.

\subsection{Perceived Usefulness:}

Internet banking services solve the problem of 'waiting time' spent in the bank to access your account or even to ask about any information or access financial needs. Since the internet banking is $24 / 7$ customers can access their banks' activities any time of the day and on any day of the week. It is considered convenient and affects adopter of e-banking services (Sohail\&Sanmugham, 2003). Working hours of banks in Egypt are inconvenient especially for people living in the capital city as in Cairo and Alexandria as being the second capital. The banks working hours are from 8:30-2:00. Because of crowdedness of banks and long waiting hours, Internet banking is considered more useful and convenient. It is characterized by a 'no queuing' service. It also minimizes the information latency. Based on the literature, the technology acceptance model is the mostly widely used to predict individual adoption of a new system or technology (Venkatsh\& Davis, 2000; Yusaff et al., 2009; Kesharwani\&Bisht, 2012). According to Ramos\& Castro (2017) perceived usefulness is determined many factors that have an effect on the system acceptance which is considered crucial in its implementation.

H2: Perceived usefulness has a positive effect on customers' attitude towards internet banking.

\subsection{Perceived ease of use:}

Perceived ease of use has been reported in many studies to have an impact on the technology adoption. Ease of use depends on the features and the website design of the bank. When the website meets an individual's expected needs by then he will be satisfied.

H3: Perceived ease of use has a positive effect on a customers' attitude toward internet banking.

\subsection{Perceived Security \& Privacy:}

It was noted by Susanto (2016) that privacy and security are considered a critical determinant of the success of internet banking. This is due to the fact that for conducting online transactions, consumers need to provide their personal and financial information, which raises concern about privacy and security issues. Based on TRUSTe survey, Akter (2014) indicated that online users are becoming more familiar with how to protect their online privacy. Moreover, Akter noted that positive attitudes decrease consumers' privacy concerns while on the other hand increased consumers' willingness for information control.

H4: Perceived privacy and security has a positive effect on customers attitude toward internet banking

\subsection{Computer efficacy:}

People exhibit more self-confidence to be involved in online transaction when they have a high degree of computer efficacy. According to Gazinoory \&Afshari-Mofrad (2012) computer efficacy was considered one of the factors that affect attitudes and intentions of users towards a system. Computer efficacy was studied and used to extend TAM.

$\mathrm{H} 5$ : Computer efficacy has a positive effect on customer attitude towards Internet banking H5a: Computer efficacy has a positive effect on customers' intentions towards internet banking

\subsection{Attitude:}

Customers use internet banking when they perceive it as useful and helpful for their transactions and interest. If customers do not perceive it as useful they will not use it and banks would lose the competitive advantage they provide. The more useful, the more internet banking will be used.

H6: Customers' attitude towards internet banking has a positive effect on their intentions towards internet banking 


\subsection{Perceived Risk:}

The separation between consumers and e-retailers in the online context generate risk towards the uncertainty of outcomes. Threats of hacking attempts decrease consumers' intention to provide their personal and sensitive information over the internet (Polasik\& Wisniewski, 2009; Kesharwani \&Bisht, 2012). Consequently, it is expected that the perceived risk would negatively affect customers' intentions to use internet banking. Consumers are likely to engage in internet banking if their risk perceptions about behavioral and transaction uncertainties, such as hacking, are lessened. ElKasheir et al., (2009) noted that perceived risk is a major factor affecting intentions.

H7: Perceived risk has a negative effect on customers' intentions towards internet banking.

\subsection{Intention:}

Intention to use is a key determinant of usage behavior as previously noted in the literature as shown in TRA and TAM (Davis et al., 1989). Turner et al., (2010) analyzed 79 empirical studies and found out that behavioral intention is a significant determinant of adoption and actual usage of a system while applying on TAM.

H8: Customers' intentions towards internet banking affect their acceptance of internet banking.

\section{Methodology}

A structured questionnaire was designed, distributed, and collected in order to study the factors that affect customers' adoption of internet banking in Egypt. A pilot testing included 30 respondents has been carried out to ensure the reliability of the scale and to modify it according to customers' comments. The questionnaire consisted of 61 items. Each item was measured using a 5 point Likert scale ranging from (1) strongly disagree to (5) strongly agree. Demographic details such as age, gender, financial income and education level were added. Moreover, respondent was asked to choose the most preferred bank name in case they have accounts in more than one bank. The population of the study was all individuals using internet banking. The statistical analysis for this study was done using the SPSS (Statistical Package for Social Science) software. Reliability Analysis (Cronbach alpha) was used to measure the reliability of factors that affect customers' adoption of internet banking. Whereas, the overall reliability of the scale was 0.968 , according to Nunnally, (1967, p.41) "A social construct might be considered as reliable whenever Cronbach Alpha coefficient is 0.45 or more. Furthermore, content validity was also ascertained by such pretesting to the questionnaire with a group of professionals and staff members. Few comments aroused and researchers managed to simplify few words and modified some of the statements.

The survey included some opening questions besides all variables according to Table (1). Two questions were developed to determine internet banking adoption which was: how frequent is your use of internet banking site? And how many times do you use internet banking?

The sample size was 220 respondents, $60 \%$ males and $40 \%$ were females. The majority of respondents' age groups were between 21-25 years of age, most of the respondents were using internet banking 2-3 times a week and at least once per month. The majority of respondents' income level were between 5000 and less than 10000.

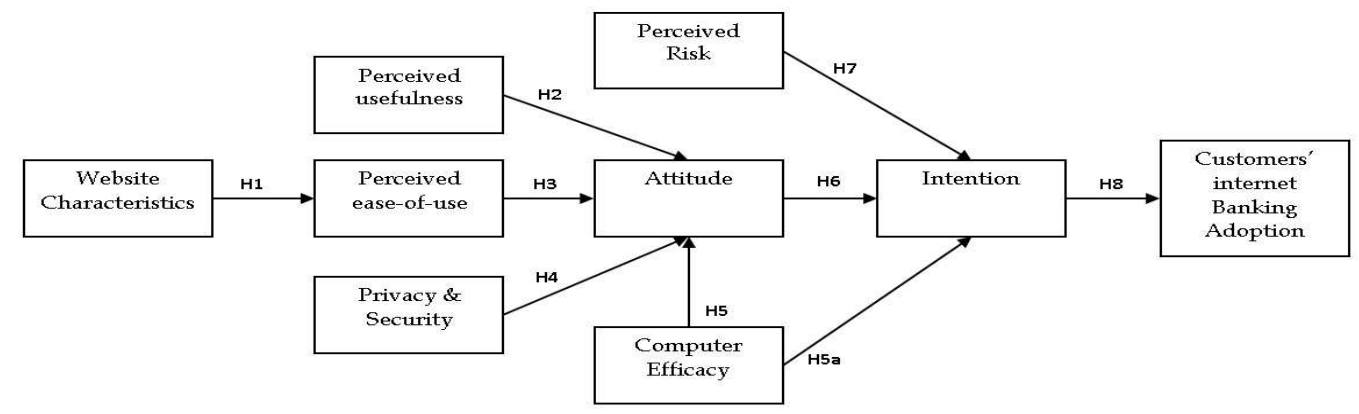

Figure1.1: Research Conceptual Model 


\begin{tabular}{|c|c|c|}
\hline Variables under study & Conceptual definition & Operational Definition \\
\hline Security/Privacy & $\begin{array}{l}\text { Security is defined as a threat which creates circumstance, condition, or event with the potential } \\
\text { to cause economic hardship to data or networkresources in the form of destruction, disclosure, } \\
\text { modification of data, denial of service and/or fraud, waste, and abuse" (Kalakota and Whinston, } \\
\text { 1997). } \\
\text { Privacy is defined as the ability to control andmanage information about oneself (Belanger et } \\
\text { al., 2002). }\end{array}$ & Adopted from Chellappa (2003) \\
\hline Computer efficacy & $\begin{array}{l}\text { Computer efficacy is defined as an individual's self- confidence in his or her ability to preform } \\
\text { tasks across multiple computer application domains (Monsuwe et al., 2004). }\end{array}$ & Adopted from Taylor \& Todd (1995) \\
\hline Perceivedusefulness & $\begin{array}{l}\text { Perceived usefulness is defined as the degree to which a person believes that using a particular } \\
\text { system would be free of effort (Davis, 1989). }\end{array}$ & Adopted from Moon \& Kim (2001) \\
\hline Perceived ease of use & $\begin{array}{l}\text { Perceived ease of use is defined as the extent to which a person believes that using a particular } \\
\text { system will be free of effort (Davis, 1989). }\end{array}$ & Adopted from Venkatesh \& Davis (2000) \\
\hline Attitude & $\begin{array}{l}\text { Attitude refersto an individual's positive or neg ative evaluation of the performance effect of a } \\
\text { particular behavior. (Ajzen and Madden, 1986). }\end{array}$ & Adopted from Taylor \& Todd (1995) \\
\hline PerceivedRisk & $\begin{array}{l}\text { Reflects consumer's perception about the uncertainty of outcomes that pertain primarily to } \\
\text { searching and choosing information of product or service before making any decision. } \\
\text { (Kesharwani and Bisht, 2012) }\end{array}$ & Adopted from Chan \& Lu (2004) \\
\hline Adoption & $\begin{array}{l}\text { According to Baraghani (2007) consumer adoption is the process that represent the procedures } \\
\text { consumers follow in making the decision of whether to use or not to use a new product or } \\
\text { service. Adoption here refers to how customers are able to use internet banking services. }\end{array}$ & Adopted from Taylor \& Todd (1995) \\
\hline Intention & $\begin{array}{l}\text { "refers to customers' intention to use, as opposed to their actual use of, IB services" (Cheng et al } \\
2006 \text { ) }\end{array}$ & Adopted from Davis \& Venkatesh (1996) \\
\hline Website characteristics & $\begin{array}{l}\text { Includes all elements of the consumer's experience at the website, including navigation, } \\
\text { information search, order processing, appropriate personalization, and product selection. (Gad, } \\
\text { 2009) }\end{array}$ & Adopted from Tarafdar andZhang (2007) \\
\hline
\end{tabular}

Table 1.1: Conceptual and operational definitions of the study variables

\section{Analysis and Results}

According to the analysis of results $40.4 \%$ of respondents used internet banking for account summary (balance statement), where 15\% used internet banking for opening an account, while 12.7\% used it for checking loan information, $10.5 \%$ used it to pay credit card dues and $10 \%$ used it for loan repayment, while $8.2 \%$ used it in checking their account details and in fund transfer among their account, $5.5 \%$ used it in viewing their credit card statements, $4.5 \%$ for checking their balance and $3.6 \%$ for exchange rates and $2.3 \%$ for checking bank statements. Frequencies showed the percentage of respondents who frequently or infrequently use internet banking. Results indicated that $58 \%$ infrequently use internet banking website, whereas $42 \%$ used banks websites. Moreover, results show how many times respondents access to the internet banking, 17.7 of respondents use internet banking once per week where $39.6 \%$ use of internet banking 2-3 times a week and $42.7 \%$ use internet banking once per month.

In order to achieve the research aim, hypotheses were tested. Based on the previous studies Website characteristics have an impact on how customers perceive the website easy to use in internet banking technology. Website characteristics were tested according to the sample of the study through testing information content, ease of navigation, usability, and customization. Kruskal-Wallis test was used to examine the significance, followed by a regression test to determine the strength of the relationship between the perceived ease of Use and website characteristics among a series of other factors affecting the use of internet banking technology. If the value (p-Value) is equal to 0.05 or less, this indicates that the dimension is significant, whereas if the p-value is greater than 0.05 , this indicates that the result is insignificant. The equation is shown below:

$\mathrm{Y}=\mathrm{a}+\mathrm{b} \mathrm{x}$, where $\mathrm{Y}$ is the dependent variable (perceived ease of use of internet banking technology), $a$, is the $Y$ intercept, that is the value of $Y$ (perceived ease of use of internet banking technology) when $x=0, b$ is the regression coefficient which indicates the amount of change in $Y$ given a unit 
change in $x$, and finally $x$ is the value of the independent variable (Web characteristics $x_{1}$ is information content, $x_{2}$ is ease of navigation, $x_{3}$ is usability and $x_{4}$ is customization). The results were as follows Kruskal Wall (P-value $=0.000$, Regression test: P-value $=0.000$, Chi-square: P-value $=$ 0.000 .

With the previously mentioned values, the hypothesis is accepted. The website characteristics affect ease of use of internet banking technology. The result obtained from the Kruskal-Wallis test is supported by the result obtained from the regression test with significant level equals to 0.000 . This shows highly significant because the value equals to 0.000 which is smaller than 0.05

Ease of use of internet banking technology $=0.952+0.181 \mathrm{x}_{1}+0.530 \mathrm{x}_{2}+0.221 \mathrm{x}_{3}+\left(-.179 \mathrm{x}_{4}\right)$. This illustrates the impact of information content, where an increase in information content by 0.181 will cause an increase in ease of use of internet banking technology by this amount, also an increase in ease of navigation by 0.530 will cause an increase in ease of use of internet banking technology by this amount as well as an increase in usability by 0.221 will cause an increase in ease of use of internet banking technology by this amount and decrease in customization by -0.179 will cause an increase in ease of use of internet banking technology by this amount.

In order to further measure the significance of the web characteristics, chi-square test was used and the value for Use of technology was equal to 0.000 , by comparing the value to 0.05 , we found 0.000 is $<0.05$. Therefore, H1 is accepted. In other words, significance was recorded, which proves that web characteristics affect ease of use of internet banking technology

Using TAM as a theoretical base, $\mathrm{H} 2$ and $\mathrm{H} 3$ were found to be significant. Perceived usefulness and perceived ease of use had a positive effect on customers' attitude toward internet banking since Pvalue of both constructs are less than 0.05. In addition to traditional constructs of TAM privacy/security, computer efficacy and perceived risk were added. H4 is supported whereas perceived privacy and security has a positive effect on customers' attitude toward banking since Pvalue less than 0.05 . During the last few years, internet transactions were attacked by hackers and many cases of theft and fraud were reported.

H5 and H5a have been tested to see the impact of computer efficacy on both customers' attitudes and intentions. Results reveal that Computer efficacy has a positive effect on customer attitude and intentions toward internet banking (P-value less than 0.05). Results show that Customers' attitude toward internet banking has a positive effect on their intentions, since P-value less than 0.05. On the other hand, perceived risk has a negative effect on consumers' intentions towards internet banking and P-value is less than 0.05. Banks should consider how to decrease customers' perceived risk on internet banking and put emphasis on safety features.

\section{Discussions and conclusions}

The study aimed at studying customers' adoption of internet banking in Egypt in the light of technology acceptance model since it is considered, based on the literature, one of the most adopted models in studying information systems acceptance. The findings from this study provide support for the theoretical model embracing TAM.

By testing hypotheses, it is clear that the website characteristics are considered one of the main factors affect customers' perception towards the ease of use of internet banking technology. This highlights the importance of identifying the web characteristics through information available over the website, ease of navigation, usability, and customization. This is in line with Alwan et al., (2016) and Alhudaithy\&Kitchen (2009) where website characteristics had a significant impact on internet banking adoption. Results reveal the significant impact of perceived ease of use and perceived usefulness on customers' attitude towards internet banking. This result is supported by previous studies such as Jahangir \& Begum (2008) which have examined the factors affecting customers' adoption of internet banking. Their study indicated that perceived usefulness and ease of use are significantly impacting customers' attitude towards internet banking. 
According to this study results indicated that perceived risk affects negatively customers' intention towards internet banking. Perceived risk has been widely discussed, and studies had shown that perceived risk is a critical factor influencing customer decisions and behaviors (Chen et al., 2016). Customers' perceived risk would have an impact on their adoption of internet banking. Lovelock et al., (2001) noted that highest adoption of a system occurs when the risk is low. This highlights that perceived risk has a negative effect on the adoption of internet banking. This is in line with Aldas-Manzano in which he argued that perceived risk increases when customers' uncertainty increases. This confirms that perceived risk weakens customers' intention towards adopting internet banking. Previously perceived risk was always noted with fraud but recently according to Algethmi (2014, p. 65) perceived risk is risk from financial, performance, social, psychological, physical or the time when customers make transactions online.

Security and privacy were found to be a real obstacle to consumers in the adoption of online systems such as online shopping, internet banking, etc. (Fawzy\& Abdel Salam, 2015; Farid, 2012), Consumers are always concerned about their credit card information and about their personal information. According to many studies, consumers are not willing to accept that they do not have full control over their own information.

\section{Managerial implication}

According to the literature, the growth of internet banking in a country depends on key success factors such as the availability of internet access, new internet banking features, the growth of internet usage by household and legal and regulatory concerns. The results of the study provide managers information about what they should consider while designing or developing their internet banking websites. Software developers should pay attention to websites characteristics. Online banking channel is considered the cheapest delivery channel for offering banking services but some concerns must be given to the level of security and privacy to provide personal and debit/credit card information. Besides you cannot change your pin code of your visa or credit/debit card to guarantee continuous security for your cards. Banks should work on developing better security levels and provide more advanced financial protection to be able to grow customers' internet banking adoption. Banking fraud cannot be eliminated without a dedicated, trusted security protocol (Mridha et al., 2017).

Determining the factors that influence customers' behavior, including constraints and key success factors would be useful for bank managers in formulating strategies aimed at benefits from providing their services online. Especially with the inconvenience in accessing different bank branches due to traffic and crowdedness, this would increase the accessibility and the acceptance of internet banking adoption. Bank managers should manage improvements of their services to deal with customers concerns.

\section{Limitation and direction for future research}

This study did not test the effect of perceived behavioral control, described in theory of planned behavior (Azen, 1991). Perceived behavioral control can explain the relationship between perceived risk and consumers intention towards internet banking. Besides that, the sample size is small although it is considered close to the sample size of other TAM studies. This affect generalization of the results. Future research can explore the antecedents and consequences of continue using internet banking for different developing countries. Moreover, future research may be conducted to extend TAM in the context of other technologies such as banks mobile applications and its effect on users' internet banking adoption.

\section{References}

Abdel Kader, M. (2013). Investigating the factors that Influence Continue Receiving Mobile SMS advertisement an empirical study applied in Egypt, (Doctoral dissertation, University of Lincoln School of Business- UK). 
Adams, D. A., Nelson, R. R., and Todd, P. A. (1992). Perceived Usefulness, Perceived Ease of Use, and Usage of Information Technology: A Replication," MIS Quarterly, 16(2), 227- 247.

Ajzen, I. (1991). The theory of planned behavior. Organizational behavior and human decision processes, 50(2), 179-211.

Ajzen, I., \& Madden, J. (1986). Prediction of goal-directed behavior: Attitudes, intentions, and perceived behavioral control. Journal of Experimental Social Psychology, 22, 453-474.

Akhlaq, A., \& Ahmed, E. (2013). The effect of motivation on trust in the acceptance of internet banking in a low-income country. International Journal of Bank Marketing, 31(2), 115-125.

Akhter, S. H. (2014). Privacy concern and online transactions: the impact of internet self-efficacy and internet involvement. Journal of Consumer Marketing, 31(2), 118-125.

Alda's-Manzano, J., Ruiz-Mafe', C. and Sanz-Blas, S. (2009). Exploring individual personality factors as drivers of m-shopping acceptance. Industrial Management and Data Systems, 109(6), 739-57.

Algethmi, M. A. (2014). Mobile commerce innovation in the airline sector: an investigation of mobile services acceptance in Saudi Arabia (Doctoral dissertation, Brunel University School of Engineering and Design PhD Theses).

Alhudaithy, A.I. and Kitchen, P.J. (2009). Rethinking models of technology adoption for internet banking: the role of web site features, Journal of Financial Services Marketing, 14(1), 56-69.

Alwan, H.A., and Al-Zubi, A.I. (2016). Determinants of Internet Banking doption among Customers of Commercial Banks: An Empirical Study in the Jordanian Banking Sector, International Journal of Business and Management, 11(3) 95 -104.

Ariff, M. (2014). Whither Islamic Banking? The World Economy, 37(6), 733-746.

Arunachalam, L. and Sivasubramanian, M. (2007). The future of Internet Banking in India, Academic Open Internet Journal, Vol. 20. Available online at: www.acadjournal.com

Baraghani, S. (2007). Factors influence the adaption of internet banking. A master's thesis presented to the development of business administration and social sciences, Lulea University of technology, Sweden

Bélanger, F., Hiller, J. \& Smith, W.J. (2002). Trustworthiness in electronic commerce: The role of privacy, security, and site attributes. Journal of Strategic Information Systems. 11(3/4), 245-270.

Chan. Siu-cheung: and Lu. Ming-te (2004). Understanding Intemet Banking Adoption and Use Behavior: A Hong Kong Perspective: Journal of Global Intonation Management, 12(3), 21-43.

Chechen, L., Yi -Jen, H. \& Tung -Heng, H. (2016). Factors Influencing Internet Banking Adoption. Social Behavior \& Personality: an international journal, 44 (9), 1443 - 1455.

Chellappa, R. (2003). Consumers' trust in electronic commerce transactions (Working Paper, ebizlab). Marshall School of Business, USC.

Chen, B. H., Chen, M. H., Hsiao, C. C., \& Chiu, W. C. (2016). Antecedents and consequences of perceived corporate social responsibility on financial holding companies - Finance students' perceptions. Journal of Management Research, 8(3), 106-122.

http://dx.doi.org/10.5296/jmr.v8i3.9611

Cheng, T. E., Lam, D. Y., \& Yeung, A. C. (2006). Adoption of internet banking: an empirical study in Hong Kong. Decision support systems, 42(3), 1558-1572.

Davis, F. D. (1989). Perceived Usefulness, Perceived Ease of Use and User Acceptance of Information Technology. MIS Quarterly. 13, 319-340.

Davis, F.D., R.P. Bagozzi, P.R. Warshaw, (1989). User acceptance of computer technology: a comparison of two theoretical models, Management Science 35 (8) 982-1003

El- Kasheir, D., Ashour, A. S., and Yacout, O. M. (2009). Factors Affecting Continued Usage of Internet Banking Among Egyptian Customers. Communications of the IBIMA, Volume 9.

El Naggar, R. A. E. A. (2010). The value of e-banking services in the Egyptian environment: an integrated model (Doctoral dissertation, University of Hull). 
Davis, F.D., Venkatesh, V. (1996). A critical assessment of potential measurement biases in the technology acceptance model: Psychological three experiments, International Journal of Human-Computer Studies 45 (1), 19-45.

Farid, S. (2012). Investigating the Factors That Affect Online Shopping Behavioral Intentions in Egypt (Doctoral dissertation, University of Lincoln School of Business- UK).

Fawzy, S. F., \& Salam, E. M. A. (2015). M-Commerce adoption in Egypt: An extension to theory of reasoned action. The Business \& Management Review, 6(1), 123.

Fishbein, M. and Ajzen, I. (1975). Belief, Attitude, Intention and Behavioral: An Introduction to Theory and Research, Addison-Wesley, Reading, MA.

Gad, K. A.(2009). Costumers' Satisfaction with Online Banking: A Case Study on HSBC Egypt.

Ghazinoory, S., \& Afshari-Mofrad, M. (2012). Ranking different factors which affect E-Learning outcomes. International Journal of Computer Theory and Engineering, 4(2), 234.

Moon, J., Kim. Y. (2001). Extending the TAM for a World-Wide-Web context, Information and Management 38 (4), 217-230.

Jahangir, N. and Begum, N. (2008). The role of perceived usefulness, perceived ease

of use, security and privacy, and customer attitude to engender customer adaptation in the context of electronic banking. African Journal of Business Management,2(1), 32-40.

Kalakota, R. \& Winston, A.B. (1997). Electronic Commerce: A Manager's Guide, AddisonWesley.

Kamyab, M., \&Delafrooz, N. (2016). Investigating the Effect of Personality Traits, Subjective Norms and Perceptions of Customers on using Internet Banking. Indian Journal of Science and Technology, 9(1).

Kesharwani, A., Bisht, S. (2012). The impact of trust and perceived risk on internet banking adoption in India: An extension of technology acceptance model, International Journal of Bank Marketing, 30(4), $303-322$

Lovelock, C.H., Patterson, P.G. and Walker, R. (2001). Services Marketing, (2nd ed). Pearson Education, French's Forest.

McKechnie, S., Winklhofer, H., and Ennew, C. (2006) .Applying the Technology Acceptance Model to The Online Retailing of Financial Services, International Journal of Retail \& Distribution Management (34: 4/5), 388-410.

Monsuwe, T.P, Dellaert, B. G. C, \&Ruyter, K. R. (2004). What drives consumers to shop online? A literature review. Int. J. Service's industry Manag. 15(1): 102-121

Mridha, M. F., Nur, K., Saha, A. K., \& Adnan, M. A. (2017). A New Approach to Enhance Internet Banking Security. International Journal of Computer Applications, 160(8).

Ndubisi, N.O. and Sinti, Q. (2006), Consumer attitudes, system's characteristics and internet banking adoption in Malaysia, Marketing Research News, 29 (1/2), 16-27.

Nunnally, J. (1967), Psychometric Theory, N.y.: Mc Graw-Hill book company, pp. 241

Ortega, B. Martinez, J. and De Hoyos, M. (2007).An analysis of web navigability in Spanish internet banking\|, Journal of Internet banking and commerce, 3(2).

Polasik, M. and Wisniewski, T.P. (2009). Empirical analysis of internet banking adoption in Poland", International Journal of Bank Marketing, 27(1), 32-52.

Qureshi, T. Zafar, M. and Khan, M. (2008). Consumer acceptance of online banking in developing economies\|, Journal of Internet banking and commerce 13(1).

Rahman, M. M. (2009). E-Banking in Bangladesh: Some Policy Implications. Policy notes.

Ramos, Y., \& Castro, A. O. (2017). Point-Of-Sales Systems in Food and Beverage Industry: Efficient Technology and Its User Acceptance. Journal of Information Sciences and Computing Technologies, $6(1), 582-591$.

Shi, W. Shambare, N. \& Wang, J. (2008). The Adoption of Internet Banking: An Institutional Theory Perspectiveee, Journal of Financial services Marketing, 12(4): 272286.

Shih, Y. \& Fang, K. (2004).The Use of A Decomposed Theory of Planned Behavior to Study Internet banking in Taiwan"e, Internet Research, 14(3): 213-223. 
Sohail, M. S., \&Shanmugham, B. (2003). E-banking and customer preferences in Malaysia: An empirical investigation. Information sciences, 150(3), 207-217.

Susanto, A., Chang, Y., \& Ha, Y. (2016). Determinants of continuance intention to use the smartphone banking services. Industrial Management \& Data Systems, 116(3), 508-525. http:/ /dx.doi.org/10.1108/IMDS-05-2015-0195

Tarafdar, M. and Zhang, J. (2007-2008). Determinants of Reach and Loyalty - A Study of Website Performance and Implications for Website Characteristics. Journal of Computer Information Systems. V. XLVIII, (2), 16-24.

Taylor, S. and Todd, P. (1995). Decomposition and crossover effects in the theory of planned behavior: a study of consumer adoption intentions", International Journal of Research in Marketing, (12), 137-55.

Turner, M., Kitchenham, B., Brereton, P., Charters, S., \&Budgen, D. (2010). Does the technology acceptance model predict actual use? A systematic literature reviews. Information and Software Technology, 52(5), 463-479.

Venkatesh, V. , Davis, F.D. (2000). A theoretical extension of the technology acceptance model: four longitudinal field studies, Management Science, 46 (2), 186-204.

Yusoff, Y.M., Muhammad, Z., Zahari, M.S.M., Pasah, E.S. and Robert, E. (2009). Individual differences, perceived ease of use and perceived usefulness in the e-library usage, Computer and Information Science, 2 (1), 76-83. 